Mavi Atlas, 8(2)2020: 490-506

Araştırma Makalesi | Research Article

Makale Geliș | Received: 20.08.2020.

Makale Kabul | Accepted: 20.09.2020.

DOI: 10.18795/gumusmaviatlas. 783062

\title{
Yasemin AKTAŞ
}

Dr. Öğr. Üyesi|Assist. Prof. Dr. Bayburt Üniversitesi, İnsan ve Toplum Bilimleri Fakültesi, Tarih Bölümü, Bayburt-TÜRKIYYE Bayburt University, Faculty of Human and Social Sciences, Department of History, Bayburt-TURKEY

ORCID: 0000-0002-0808-8874

yaseminaktas@bayburt.edu.tr

\section{Salgurlular'da Naibe Türkan Hatun ve Atabeg Abiş Hatun'un İdaresi}

$\ddot{\mathrm{O} z}$

Salgurlular, Şîrâz merkezli olarak kurulmuş bir devlettir. Kuruluş döneminde Irak Selçuklularına, ardından Harezmşahlara bağlı olan Salgurlular, son dönemde İlhanlı tabiiyetine girdi. Fars bölgesindeki İlhanlı hâkimiyeti, Atabeg Ebu Bekr b. Sa'd'ın haraç vermeyi kabul etmesiyle başladı ve sonrasında da devam etti. Atabeg Ebu Bekr ve oğlu II. Sa'd sonrasında Salgurlular'da Türkan Hatun ve kızı Abiş Hatun'un liderlik yaptığı, İlhanlı valilerinin yönetime müdahil olduğu süreç başladı. Türkan Hatun, ilk olarak oğlu Muhammed'in naibesi olarak göreve başladı. Hatun, naibelik süresince İlhanlılarla sulh siyaseti izledi. Oğlu Muhammed'in ardından damadı Muhammed-şâh b. Salgur-şâh'ın atabegliğinde de devlet idaresinde etkisini hissettirdi. Damadı Muhammed-şâh'ın kendisini yönetimden uzak tutmak istemesi üzerine onu bertaraf eden Türkan Hatun, Selçuk-şâh b. Salgurşâh'ı atabeg tayin ettirdi. Lakin Türkan Hatun'un naibeliği, eşi Selçuk-şâh tarafindan öldürülmesiyle son buldu. Selçuk-şâh'1n siyasî hataları, Salgurlular'ın yıkılış sürecini başlattı. Kazerun Savaşı sonrasında öldürülmesiyle de Salgurlular'ın son lideri olan Abiş Hatun atabegliğe getirildi. Atabeg Abiş’in saltanatında yerel idarecilerle İlhanlı emirleri arasında nüfuz mücadelesi yaşandı. İlhanlı valilerinin etkili olduğu son dönemde siyasî ve askerî mücadelelerin yanı sıra İlhanlıların malî soygunları ile 3 yıl süren kıtlık dönemi de büyük bir sarsıntıya sebep oldu. Argun Han'ın naibi Seyyid İmadeddin ile yaşanan anlaşmazlık ve İmadeddin'in öldürülmesi Salgurlular'ın sonunu getirdi. Argun Han'ın emri doğrultusunda Şîrâz ileri gelenleri yargılandı ve cezalandırıldı. Abiş Hatun da bundan bir yıl sonra hastalanarak hayatını kaybetti. Abiş Hatun'un ölümüyle Fars bölgesindeki Salgurlu hâkimiyeti son buldu.

Anahtar Kelimeler: Salgurlular, Abiş Hatun, Türkan Hatun, Şîrâz.

\section{Naibe Türkan Hatun in Salghurids and the Administration of Atabeg Abiş Hatun}

\section{Abstract}

The Salghurids are a state established in Shiraz. The Salghurids who were affiliated to the Iraqi Seljuks and then Harezmşahs in the period of their establishment, recently controlled by the Ilkhanate. Ilkhanate domination in the Persian region started when Atabeg Abu Bekr Sa'd agreed to pay tribute and then continued. After the reign of Atabeg Abu Bakr and his son II., the process in which Turkan Hatun and his daughter Abiş Hatun took the leader, and the governors of Ilkhanate took over, began in the Salghurids. Turkan Hatun first took the office as the regent of her son Muhammed. Hatun followed the peace policy with the Ilkhanate during his regency. She also made her influence in the state administration, in being an atabeg of her son-in-law Muhammed-shah b. after the reign of his son Muhammad. Türkan Hatun, who dismissed him when her son-in-law Muhammed-shah wanted to keep her away from the administration, appointed Selçuk-shah b. Salgurshah as atabeg. However, the regency of Türkan Hatun ended when she was killed by her husband Selçuk-shah. The political mistakes of Selçuk-shah started the process of the collapse of the Salghurids. When he was killed in the Battle of Kazerun, Abiş Hatun, the last leader of the Salghurids, was appointed as the atabeg. During the reign of Atabeg Abiş, there was a struggle for authority between local administrators and Ilkhanate orders. In addition to the political and military struggles in the last period when the governors of Ilkhanate were effective, the financial robberies of Ilkhanate and the famine that lasted for 3 years caused a great shock. The dispute with Seyyid Imadeddin, the regent of Argun Han and the murder of Imadeddin, brought the end of the Salghurids. In the line with the orders of Argun Han, the notable people of Shiraz were put in trial and punished. Abiş Hatun fell ill and died a year later. With the death of Abiş Hatun, Salgurlu rule in the Persian region ended.

Keywords: Salghurids, Abiş Hatun, Türkan Hatun, Shiraz. 


\section{Giriş}

Tarih boyunca kadınlar, hayatın her evresinde yer almışır. Kadınlar, vakıflar kurarak hayır işleriyle meşgul oldukları gibi devlet yönetiminde ve devletlerarası siyasetin şekillenmesinde de etkili olmuşlardır. Ortaçağ süresince Türk tarihinde pek çok kadın lider olup Selçuklu Devletleri, Harezmşahlar, Memlükler, Kutlughanlar ve birçok devlette bunların örneklerine rastlanmaktadır. Bu devletlerde kadınlar, siyasî, sosyal ve kültürel süreçlere yön vermede oldukça etkili olmuşlardır. ${ }^{1}$ Kadın liderlerin varlığına verilebilecek bir diğer örnek de Fars Atabegliği olan Salgurlulardır. Salgurlular'da Sungur b. Mevdud'dan itibaren 11 atabegin adı zikredilmekte ve bu atabegler arasinda kadınlar da yer almaktadır. Özellikle Atabeg II. Sa'd'ın ölümünden sonra Salgurlular'da İlhanlı hâkimiyetinin hissedildiği ve kadın hükümdarların etkili olduğu süreç başladı. Salgurlular'da atabeglik makamında bulunan kadın liderler, naibe Türkan Hatun ve kızı Atabeg Abiş idi (Karakoç, 1998: 124). Bu iki kadın, Salgurlu siyasetine yön verdi ve hanedanın devamını sağlamak adına girişimlerde bulundu.

Salgurlular, soy itibariyle 24 Oğuz boyundan Üçoklara, Salur ya da Salgur adıyla bilinen Türkmen beyine dayanmaktadır. Salgur Bey, Selçuklu Devleti’nde ordu komutanlığ1 görevinde bulundu (Kazvînî, 1913: 118-120; Merçil, 1991: 28-30; Sümer, 2016: 325-326). Türkmen beyi Salgur, Irak Selçuklu Sultanı Tuğrul'un Emîr-i Hacibi olarak görev yaptı. Salgur'un torunlarından olan Sungur b. Mevdud, Irak Selçuklu Devleti'ne isyan ederek Fars bölgesinde bağımsızlığını ilan etti (542/1147-1148). Türkmen emirlerinin ve 50 bin süvarinin desteğini alarak Şirâz ${ }^{2}$ merkezli olmak üzere Salgurlu Atabegliği'ni kurdu (Gaffârî, 1343: 125-126; Mîrhând, 1848: 23-24; Şebânkârê̂, 1363: 182-184; Kadyânî, 1381: 343).

Salgurlu Atabegliği'ne en parlak dönemini yaşatan lider Ebu Bekr b. Sa'd oldu (Mîrhând, 1848: 33; Şebânkâreî, 1363: 184; Merçil, 1991: 85). Fetih hareketleri doğrultusunda Fars bölgesinde geniş bir alana hâkim olan Salgurlular, Moğolların batıya yönelmesi üzerine büyük bir tehlike ile karşı karşıya kaldı. Moğolların gücünün farkında olan Atabeg Ebu Bekr, Fars bölgesini Moğol saldırılarından korumak için girişimlerde bulundu. Bu doğrultuda aile üyelerinden ve Şîrâz ileri gelenlerinden oluşan heyeti, hediyelerle birlikte Moğol Hanının huzuruna gönderdi. Ebu Bekr'in bu şekilde tabiliğini bildirmesinin ardından Moğol Han'ı şahnelerini Şîrâz'a gönderdi. Atabeg Ebu Bekr, onlara tabilik bildirmiş olmakla birlikte Şîrâz'da Moğol varlı̆̆ını istememekteydi. Bu nedenle Şîrâz’a gelen heyetin konaklama yerlerinin şehrin dışında hazırlanmasını emretti. Ayrıca Şirâzz halkının da onlarla konuşmasını ve temasa geçmesini yasakladı (Mirhând, 1848: 38). Ebu Bekr, devletin bekası ve sükûneti korumak adına Moğollara karşı sulh yolunu izlerken gerekli tedbirleri de almayı ihmal etmedi. Hülâgû Han'in isteklerini yerine getirme konusunda tereddüt göstermeyen Ebu Bekr, Han'ın isteği doğrultusunda itaatini yineledi ve kardeşinin oğlu Selçuk-şâh b. Salgur-şâh'1 1255 yllında Hülâgû Han’a gönderdi (Mîrhând, 1848: 38; Merçil, 1991: 94; Üçok, 2011: 154). Sâdî Şîrâzî’de kendisinden övgüyle bahsedilen Ebu Bekr'e (Sâdî-̂̂ Şîraẑ̂, 1980: 21-24, 311-313) sadakatinin karşılı̆̆ında "Kutluk Han” lakabı verildi (Mîrhând, 1848: 33).

\footnotetext{
${ }^{1}$ Türk İslam Devletlerinde kadın hükümdarlar konusunda bk. Bahriye Üçok (2011). İslâm Devletlerinde Türk Nâibeler ve Kadın Hükümdarlar, İstanbul: Bilge Kültür Sanat; Samira Kontamir (2011). "Memlûk Toplumunda Kadın", Ortaçağ'da Kadın, ed. Altan Çetin, ss. 605-620, Ankara: Lotus Yayınevi; Cihan Piyadeoğlu (2011). "Büyük Selçuklu Coğrafyasında Yaşamış Kadın Âlimler”, Ortaçağ da Kadın, ed. Altan Çetin, ss. 459-469, Ankara: Lotus Yayınevi; Ahmet Ocak (2011). "Selçuklu İlim ve Tefekkür Hayatında Kadınların Yeri”, Ortaçağ’da Kadın, ed. Altan Çetin, ss. 420-458, Ankara: Lotus Yayınevi; Ensar Macit (2019). “Celâyirliler'de Kadın ve Siyaset”, Selçklu Araştırmalar Dergisi, 11: 11-36. 2 Salgurlular'ın merkezi olan Şîrâz, müellifler tarafından güzellikleriyle anlatılmaktadır. Geniş ve düz bir alana kurulmuş olan Şîrâz, nehirleri, bahçeleri ve gösterişli yapılarıyla doğunun gözde şehirleri arasında yer almaktadır. Şam ile kıyaslanan ve güzelliğiyle göz kamaştıran şehir, bakımlı caddelere ve çarşılara sahiptir. Her meslek erbabına ait özel çarşılar bulunmaktadır (İbn Battûta, I, 2004: 284-300). Ayrıca Kazvînî, Şirầz’1, Fars bölgesinin Kubbetü’l İslâm’1 olarak tarif etmektedir. Âlim ve evliya yurdu olarak tanımlanan Şîrâz'da (Kazvînî, 1919: 114) farklı mezhebe ve dine mensup insanlar bir arada yaşamaktaydı (Benjamin ve Petachıa, 2009: 101).
} 
İleri görüşlü bir devlet adamı olan Ebu Bekr, Fars bölgesinde istikrarı sürdürebilmek amacıyla Moğollara haraç ve hediye göndermeyi ihmal etmedi. Ebu Bekr b. Sa'd, Bağdad seferi öncesi kendisinden destek isteyen Hülâgû'ya Muhammed-şâh b. Salgur-şâh'1 gönderdi. Bağdad ve Luristan'da elde ettikleri zaferlerin ardından da oğlu II. Sad'ı, ileri gelenlerden bir grup ve değerli hediyelerle birlikte İlhanlı hanı Hülâgû'ya gönderdi (Mîrhând, 1848: 38-39; Şebânkârê̂, 1363: 185; Uygur, 2019: 222-223). Bu, onun ölmeden önceki son girişimi oldu. Ebu Bekr’in izlediği siyaset Fars bölgesinde Moğol hâkimiyetinin artmasına zemin hazırladi. Hülâgû Han, Salgurlular üzerindeki kontrolün devamı amacıyla Ebu Bekr'in son günlerinde Emir Altacu'yu Şîrâz'a yolladı (Kasım-Aralık 1259). Altacu, Şîrâz'da bir takım düzenlemeler yaptı ve Salgurlular ile akrabalık tesis ettikten sonra geri döndü (Merçil, 1991: 95).

Salgurlular'a en güçlü dönemini yaşatan ve erdemli bir lider olarak tarif edilen Ebu Bekr b. Sa'd, 18 Mayıs 1260 tarihinde Şîrâz'da hastalanarak hayatını kaybetti (Benâketî, 1348: 408; Gaffârî, 1343: 127; Reşîdüddin, 1947: 253; Merçil, 1991: 98). 30 yıllık saltanatının ardından onun ölümüyle Fars bölgesinde karışıklıklar başladı. Ebu Bekr'in son zamanlarında oğlu II. Sa'd, tabilik-metbuluk ilişkisi çerçevesinde Hülâgû Han'ın yanına gitmişti. Han'dan aldığı fermanla dönüşü sırasında II. Sa'd hastalandı. Hastalığılyla meşgul olduğu esnada ise babasının ölüm haberi iletildi ve Salgurlu Atabegliğine getirildi. Fakat II. Sa'd'ın liderliği çok uzun sürmedi ve Atabegliğe geldikten kısa süre sonra 37 yaşında hayatını kaybetti. Atabeg II. Sa'd, hatunu Türkan tarafından Şîrâz'da inşa edilen Adudîye Medresesine defnedildi. II. Sa'd öldüğünde geride Muhammed adında bir oğlu, Abiş ve Salgom Hatun adlarında iki kızı kaldı (Reşîdüddîn, II, 1373: 935; Vassâf, 1346: 106; Şîrâzî, 13101350: 61; Kaska, 2019: 334-335). II. Sa'd'nn atabeglik süresi konusunda kaynaklarda farklı bilgiler mevcuttur. Müelliflerin bir kısmı babasından 12 gün sonra hayatını kaybettiği bilgisini verirken (Reşîdüddîn, II, 1373: 935; Kazvînî, 1923: 121; Benâketî, 1348: 408; Gaffârî, 1343: 127; Şebânkâreî, 1363: 185), Şîrâznâme'de 17 gün atabeylik yaptığı bildirilmektedir (Şîrâzî, 1310-1350: 62). Târih-i Vassâf ta ise atabegliğinin 18. gününde öldüğü zikredilmektedir (Vassâf, 1346: 106).

\section{Muhammed b. Sa'd'ın Atabegliği ve Türkan Hatun'un Naibeliği}

II. Sa'd'ın ölümünden sonra yaşanacak siyasî boşluk, Salgurlular üzerindeki İlhanlı nüfuzunun artmasına sebep olabilirdi. Atabeglik makamının boş kalmasını istemeyen Fars bölgesinin ileri gelenleri, onun 12 yaşındaki oğlu Muhammed'i atabeglik makamına getirdiler. Saltanata getirilen Muhammed'e, Aduddîn lakabı verildi (Vassâf, 1346: 106; Reşî̉düddîn, II, 1373: 936). Muhammed'in yaşının devleti idare etmeye uygun olmaması sebebiyle annesi Türkan Hatun'un naibe tayin edilmesine karar verildi (Şîrâzî, 1310-1350: 62; Reşî̀üddîn II, 1373: 935-936; Şebânkârê̂, 1363: 185; Kazvînî, 1913: 121; Mîrhând, 1848: 39). Türkan Hatun'un 1260 tarihinde naibeliğe getirilmesiyle, Fars Atabegliğinde ilk defa kadın lider dönemi başlamış oldu (Merçil, 1991: 99-100).

Türkan Hatun'un babası, devlet işlerinde adaletten ayrılmayan, âlimleri himaye eden ve ibadetle meşgul bir idareci olarak tarif edilen Yezd Atabegi Kutbeddin Mahmûd-şâh'tı (Benâketî, 1348: 408; Reșîüddîn, II, 1373: 936). Annesi ise Kirman emiri Barak Hâcib’in kızı Yâkut Terken'di. (Gaffârî, 1343: 127; Gençtürk, 2016: 100; Çalısskan, 2017: 37-39; Okumuş, 2012: 61). Tarih boyunca Türk-İslam devletlerinin birçoğunda devletlerin menfaati doğrultusunda siyasî evlilikler yapıldığ1 bilinmektedir. ${ }^{3}$ Kirman meliki Kutbeddin'in de siyasî şartlar gereği kızı Türkan Hatun'u Fars Atabegi II. Sa'd ile evlendirdiği anlaşılmaktadır.

İcraatlarından da görüleceği üzere hırslı bir hatun olan Türkan, naibe tayin edildiği andan itibaren Salgurlu yönetiminde büyük nüfuz sahibi oldu. Hatun, devlet idaresine geldiğinde yönetimi düzenlemek, halkın refahını sağlamak ve kendisine taraftar bulmak amacıyla girişimlerde bulundu (Reşîdüddîn, II, 1373: 936; Benâketî, 1348: 408; Mîrhând, 1848: 39). İlk olarak, devlet adamlarının

\footnotetext{
${ }^{3}$ Detaylı bilgi için bk. Ergin Ayan (2017), Ortaçağ Türk Devletlerinde Hanedan Evlilikleri, Ankara: Gece Kitaplığı.
} 
desteğini elde edebilmek için atabeglik hazinesinden ihsanlarda bulundu. Ardından devlet idaresinde düzenlemeler yapan hatun, kendisine yakın kişileri önemli görevlere getirdi. Şîrâz'in ileri gelenlerinden Hoca Nizâmeddîn Muhammed'i vezirlik makamına tayin etti ve Hülâgû'nun huzuruna gönderdi. Türkan Hatun, değerli hediyeler ve bağlllığını bildirdiği mektubu karşllğ̆nda oğlunun atabegliğini meşru kılan bir yarlıg almayı başardı (Mîrhând, 1848: 39; Vassâf, 1346: 106; Üçok, 2011: 155). Türkan Hatun'un naibeliğinin ilk yıllarında İlhanlılara karşı sulh yolunu izlediği anlaşılmaktadır. Yönetimde tam bir otorite kurabilmek için kendisine muhalif olabilecek tüm devlet erkânını ortadan kaldırmak isteyen Hatun, ilk olarak Ebu Bekr b. Sa'd'ın veziri Emir Fahreddîn'i öldürttü. Târih-i Vassâfta yer alan bilgiye göre bu emir, sarayın nimeti ile yetiştiğini ifade ederek itaatini bildirmişse de Türkan Hatun'un emriyle gizlice öldürüldü (Vassâf, 1346: 106).

Türkan Hatun, Fars bölgesinde sükûneti bir türlü sağlayamadı. Hatun, Şirâz'da düzeni sağlamaya çalışırken Şîrâz halkı Hatun'u uğursuz addetti ve ona karşı olumsuz bir tutum gösterdi. Halk, Türkan Hatun'un, II. Sa'd'ın gulamı Şemseddin Miyak ile ilişkisi olduğu yönünde ithamda bulundu. Bu şekilde olumsuz bir tavır sergilenmesinin nedeni, eski vezir Emir Fahreddîn'in öldürülmesinden kaynaklanmış olmalıydı. Zira Hatun'un, halkın tepkisine sebep olabilecek başka bir olumsuz tutumu bulunmamaktaydı. Tüm suçlamalara ve halkın olumsuz söylemlerine rağmen Hatun, atabegliğin huzuru ve halkın rahatı için çalışmaya devam etti. Türkan Hatun'un naibeliği oğlu Muhammed'in sarayın damından düşerek hayatını kaybetmesiyle 1262 yılında sona erdi. Çocuk yaşta tahta çıkarılan Muhammed, sadece 2 y1l 7 ay süreyle Atabeglik makamında bulunmuş oldu (Kazvînî, 1913: 121; Mîrhând, 1848: 39; Vassâf, 1346: 106; Şîrâzî, 1310-1350: 62). Müellifler nakillerinde Muhammed'in atabegliğine ve icraatlarına dair fazla bilgiye yer vermemektedir. Lakin Şeyh Sâdî-1 Şîrâzî, Babtiyar bir șabtır. Tabt ve tacon sabibidir. Gençtir, taliblidir, parlak fikirlidir. Sanatça genç, rey ve tedbirce ihtiyarder. İlimce büyü̈k, bimmetce yücedir. Kolca kuvvetli, kalbi pek müdrik, pek, hassastır. Zaman annesi için ne devlettir ki böyle bir çocuğu kucağında beslemiştir (Sâdî-1̂ Şîrazî, 1980: 25-26) sözleriyle Muhammed'in atabegliğine övgülerde bulunmaktadır.

Ak1llı bir kadın olan Türkan Hatun, oğluna naibe tayin edildiği ilk andan itibaren memleketin siyasî ve sosyal işlerinde tedbirler alma yoluna gitmişti. Tayin ve azillerin yanı sıra kendinden önceki atabeglerin hazinelerini halkın ve askerîn ihtiyacı için kullanması, refah seviyesini yükseltti. Atabegliğin çöküşünün başladığı bu dönemde, Salgurluları her türlü saldırıdan korumaya çalıştı (Mîrhând, 1848: 39). Türkan Hatun oğlu Muhammed'in birkaç gün süren taziye merasiminden sonra devlet işlerinin ihmal edildiğini ve yönetimde bozulmaların yaşandığını gördü. Memleketin ileri gelenlerinden danışma meclisini toplamalarını ve atabegliğe uygun olan bir kimseyi lider tayin etmelerini istedi. Türkan Hatun'un emri doğrultusunda Salgurlulara atabeg seçilmesi için yeni bir istişare meclisi toplandı (Mîrhând, 1848: 39; Vassâf, 1346: 107).

\section{Atabeg Muhammed-şâh b. Salgur-şâh}

Türkan Hatun, oğlunun ölümünden sonra bir süre daha devlet yönetiminde söz sahibi olmaya devam etti. Naibelikten ayrılmak istemediği anlaşılan hatun, yas günlerinin ardından Şirâzz ileri gelenleriyle atabeglik makamına kimin geçeceği konusunda istişarede bulundu. Neticede Șirâz ileri gelenleri, Hülâgû Han'ın yanında bulunan Muhammed-şâh b. Salgur-şâh'ın üzerinde fikir birliği sağladılar (Kazvînî, 1913: 121; Benâketî, 1348: 408; Şîrâzî, 1310-1350: 62). II. Sa'd'ın, Muhammed'den başka oğlu kalmaması, hanedan üyesi Muhammed-şâh'ın, Salgurlu tahtına çıkarılmasını zorunlu kılmışıı (Şebânkârê̂, 1363: 185). Muhammed-şâh, Bağdad zaptı sırasında Hülâgû'nun yanında gösterdiği cesaretiyle takdir edilmişti. Onun Atabeg tayin edilmesinde Hülâgû Han nezdindeki konumu ve Türkan Hatun'un kızı Salgom Hatun ile 1259'da yaptığı evliliği de oldukça etkili oldu (Vassâf, 1346: 107; Mîrhând, 1848: 39-40; Merçil, 1991: 101). Atabegliğe atandiktan kısa süre sonra tüm yetkiyi tek elinde toplamayı başaran Muhammed-şâh, Istahr Kalesi'nde hapsedilmiş olan kardeşi Selçuk-şâh'ın, aman dileyen mektubunu cevapsız birakarak O'nu hapiste tutmaya devam etti (Vassâf, 1346: 107; Benâketî, 1348: 408). 
Muhammed-şâh, askerî başarıları üzerine devletin menfaati doğrultusunda atabegliğe getirilmiş olmasına rağmen kendisinden beklenilen liderliği gösteremedi. $\mathrm{O}$, atabegliğin menfaatine işler yapmak yerine eğlence meclislerinde fazlaca vakit geçirdi. Türkan Hatun da yönetim üzerindeki otoritesini damadı Muhammed-şâh vesilesiyle sürdürmek istemekteydi. Lakin atabeg, yönetimden uzaklaşıp devlet işlerini ihmal ettiği gibi hatunun sözlerini dikkate almayarak onu yönetimden uzak tutmak istedi. Ayrıca hatunu destekleyen devlet adamlarına karşı sert bir tutum sergiledi. Muhammed-şâh'n yönetiminden hoşnut olmayan emirler, ondan kurtulmak için Türkan Hatun ile görüştüler. Yaptıkları plan doğrultusunda Muhammed-şâh'ı hareme girdiği sırada yakalayarak esir aldılar (Mîrhând, 1848: 41-42; Vassâf, 1346: 107; Karakoç, 1998: 128-129). Esir alınan Muhammedşâh'a dokunulmazken yanında bulunan oğlu ve yakınları öldürüldü (Şebânkârê̂, 1363: 185-186). Türkan Hatun, bir yandan Hülâgû Han'1n öfkesinin önüne geçmeyi, diğger yandan Muhammed-şâh'1 bertaraf edişini meşru bir zemine oturtmayı arzulamaktaydı. Bu nedenle Muhammed-şâh'ın atabeglik sorumluluğuna sahip olmadığını, suçsuz insanları öldürdüğ̈nü ve memleketi harap duruma getirdiğini bildiren bir mektup yazdı. Bu mektupla birlikte esir ettiği Muhammed-şâh’1 Hülâgû Han’a gönderdi. Muhammed-şâh atabegliğinin ilk zamanında Hülâgû Han tarafindan huzura çağırrlmış lakin o bu emri de yerine getirmemişti. Onun bu itaatsiz tutumu göz önünde bulundurulduğunda sunulan gerekçeler kabul edildi ve Türkan Hatun'un yaptığı mâzur görüldü. Türkan Hatun, bu girişimiyle atabeglik için büyük bir tehlike olan İlhanlılarla sulh ortamının bozulmasinı önlemiş oldu (Mîrhând, 1848: 41-42; Vassâf, 1346: 107; Şîrâzî, 1310-1350: 63). Muhammed-şâh, isnad edilen suçlara binaen Tebriz'de yarg1landıysa da suçsuz bulundu. Mahkeme sonrası Hülâgû Han yeni bir yarlığ hazırlanmasını ve Muhammed-şâh'ın geri gönderilmesini emretti. Fakat hazırlıkların yapıldığı esnada Selçuk-şâh'n İlhanlılar aleyhine eylemleri haber alınınca Muhammed-şâh’1 serbest bırakmaktan vazgeçerek cezalandırdı (Şebânkâreî, 1363: 186).

Muhammed-şâh'ın, 8 ay süren atabegliği Türkan Hatun'un girişimiyle 18 Temmuz 1263'te (10 Ramazan 661) (Mirhând, 1848: 42; Kazvînî, 1913: 121; Gaffârî, 1343: 127) esir alınarak Hülâgû Han'a gönderilmesi ve burada idam edilmesiyle son buldu (Şîrâzî, 1310-1350: 63; Vassâf, 1346: 107108; Mirhând, 1848: 42). ${ }^{4}$

\section{Selçuk-şâh b. Salgur-şâh'ın Atabegliği ve Naibe Türkan Hatun'un Öldürülmesi}

İktidar hırsıly hareket eden Türkan Hatun, kendisini yönetimden uzak tutmak isteyen Muhammed-şâh'ı kolaylıkla bertaraf etti. Eski atabegin, liderlik vasıflarından yoksun olması ve Türkan Hatun'un Hülâgû Han ile akrabalığının, onun işlerini kolaylaştırdığı şeklinde değerlendirilebilir. Muhammed-şâh'ın azledilmesi, onun yönetiminden memnun olmayan ahali nezdinde büyük sevinç yarattı ve Şîrâz'da eğlenceler tertip edildi. Fars Atabegliğ̣inin lidersiz kalmasını istemeyen Türkan Hatun, vakit kaybetmeden yeni bir atabeg arayışına girdi. Yapılan istişare neticesinde Istahr Kalesi'nde esir olan Selçuk-şâh b. Salgur-şâh'1 atabeg tayin etti (Vassâf, 1346: 108; Mîrhând, 1848: 42-43; Şîrâzî, 1310-1350: 63). Selçuk-şâh'n atabegliğe getirildiği tarihe kadar Salgurlular 9 ay süreyle lidersiz kaldı (Şebânkârê̂; 1363: 186). Müellifler tarafindan fiziki olarak gösterişli bir surete sahip olduğu ifade edilen Selçuk-şâh, anne tarafindan soy olarak Selçuklulara dayanmaktaydı (Mîrhând, 1848: 42; Şîrâzî, 1310-1350: 63; Karakoç, 1998: 129). Salgur-şâh'ın oğlu olması ve Selçuklu hanedanıyla olan akrabalığı, atabegliğe getirilmesinde önemli etkenlerden say1labilir.

Selçuk-şâh, atabegliğe geldiği zaman ilk olarak kendisine muhalif olabilecek devlet adamlarını ortadan kaldırdı. Selçuk-şâh da kardeşi Muhammed-şâh gibi atabegliğini Türkan Hatun ile paylaşmak niyetinde değildi. Fakat hatunun devlet adamları üzerindeki etkisinin farkındaydı. Selçuk-şâh, hem Türkan Hatun'un nüfuzundan faydalanmak hem de onu kontrol altında tutabilmek

\footnotetext{
${ }^{4}$ Müellifler Muhammed-şâh'n atabeglik süresi konusunda farklı bilgiler vermektedir. Muhammed-şâh'n atabegliğinin 7 ay (Şebânkâreî, 1363: 186), 5 ay (Şîrâzî, 1310-1350: 63; Benâketî, 1348: 409) ve 4 ay (Vassâf, 1346: 108) sürdüğü yönünde bilgiler nakledilmektedir.
} 
amacıyla onunla evlendi. Türkan Hatun, naibeliğini sürdürmek ve eşi vesilesiyle yönetime ortak olmak niyetiyle bu evliliği gerçekleştirmiş olmalıdır. Ancak bu beklentisinin tam aksine hatun, Selçuk-şâh tarafindan yönetimden uzak tutuldu. Selçuk-şâh, Türkan Hatun'u yönetimden uzaklaştırdı ardından da Salgurlular'ın tüm hazinesini tasarrufuna aldı (Vassâf, 1346: 108; Mîrhând, 1848: 43; Üçok, 2012: 156-157). ${ }^{5}$ Türkan Hatun'la evlenmesi ve Atabegliğin maliyesine el koymas1 sayesinde Salgurlular üzerindeki otoritesini güçlendirmiş oldu.

Selçuk-şâh, atabegliğe geldikten bir süre sonra devlet işlerinden uzaklaşarak sefahate düşkün bir hayat yaşamaya başladı. Mîrhând'ın ifadesine göre atabeg, liderliği esnasında Türkan Hatun'un güzelliğine âşık olsa da kendisini ve müstakil hâkimiyetini koruma arzusuna da sahipti (Mîrhând, 1848: 43). Evlilik akdinden birkaç ay sonra Selçuk-şâh, bir gece eğlencesinde gözüne takıllan zenci bir köleyi yanına çağırdı ve Türkan Hatun'un başını kendisine getirmesini emretti. Emri derhal yerine getiren köle, Türkan'ı yakalayarak başını gövdesinden ayırdı ve altın bir leğen içinde Selçukşâh’a getirdi. Selçuk-şâh sarhoşluğun etkisiyle Türkan Hatun'un kesik başındaki her biri Misır ve Şam haracıyla eş değerde olan küpeleri alarak şarkıcıların önüne attı (Vassâf, 1346: 108; Mîrhând, 1848: 43-44). Türkan Hatun'un beklenmedik ölümüyle geride kalan Abiş ve Salgom adlı kızları ise Selçuk-şâh'1n emriyle Sefid Kalesi'ne hapsedildi (Reşîüddîn, II, 1913: 936; Benâketî, 1348: 409; Merçil, 1991: 103-104). Türkan Hatun'un öldürülmesine dair çeşitli gerekçeler sıralanmaktadır. Bahriye Üçok tarafından Türkan Hatun'un öldürülmesinde onun nüfuzunun kırılmak istenmesinin ve Muhammed-şâh'ın intikamının alınmak istenmesinin etkili olabileceği ifade edilmektedir (Üçok, 2011: 157). Şîrâznâme'de yer alan bilgiye göre ise Selçuk-şâh, hayatına kastettiği yönünde ithamda bulunduğu Türkan Hatun'un ölüm hükmünü verdi (Şîrâzî, 1310-1350: 63). Şîrâznâme'de nakledilen son bilgiyle İlhanlılarla akrabalığı bulunan Türkan Hatun'un ölümünün haklı gerekçelere dayandırılmak istendiği anlaşılmaktadır. Neticede Salgurlular'ın ilk kadın lideri olan Türkan Hatun, iktidar mücadelesi neticesinde eşi tarafından ortadan kaldırıldı. Sâdî-î Şirâzî̀den nakille;

\begin{abstract}
Ne dua edeyim sana ey devletin uğurlu gölgesi, Ya rabbi bu kutlu gölgeyi İslam'ın başında daim eyle. Cömertliği aşikârdır ama varlığı halkın nazarından gizlidir. Adı âlemde ve kendisi Allah'ın inayeti altındadır. Haramdan uzak durup ibadetle meşguldür. Otağının kapısında padişahlar beklemektedir. İyiliğini isteyenlerin başında keramet tacı var. Kötülügünü isteyenlerin ayaklarında işkence zinciri var, sözleriyle hatundan övgüyle bahsedilmektedir (Kaska, 2019: 340).
\end{abstract}

Türkan Hatun’un beklenmedik ölümü, ertesi gün Moğol şahneleri Kutluğ Bitikçi ve Oğul Beg ile tüm Şîrâzlılar tarafından duyuldu. Olayın ortaya çıkmasıyla birlikte Selçuk-şâh, yaptıklarını inkâr etti. Ayrıca Han'ın huzuruna çıkarak özür dilemek ve mazeretini bildirmek istediğini iletti. Han, Selçuk-şâh'ın huzura çıkmasını kabul etti lakin $O$, hanlığa gitmek yerine eğlence meclislerinde vakit geçirmeye devam etti (Mîrhând, 1848: 44). Hatun ile aynı akıbete uğramak istemeyen Moğol şahneleri ise Hülâgû Han'ın yanına gittiler. Onların huzura çıkışını engellemek isteyen Selçuk-şâh ise ilk olarak Oğul Beg'i ardından da Kutluğ Bitikci ve tüm yakınlarını öldürttü (Vassâf, 1346: 108; Şîrâzî, 1310-1350: 63; Sümer, 1988: 310). Ebu Bekr b. Sa'd, II. Sa'd ve Naibe Türkan, Moğollara karşı sulh yolunu izlerken Selçuk-şâh farklı bir siyasî tutum sergileyerek mücadele sürecini başlattı. Selçuk-şâh'ın sebep olduğu karmaşada Şemseddin Miyak, Hülâgû'nun yanına kaçarak Türkan Hatun ve İlhanlı emirlerinin öldürüldüğü bilgisini ulaştırdı. Şîrâz'da yaşananları öğrenen Hülâgû Han, suçsuz bularak serbest bırakmayı düşündüğü hanedan üyesi Muhammed-şâh'1 idam ettirdi ve bu şekilde ilk tepkisini göstermiş oldu (Mîrhând, 1848: 45; Şebânkâreî, 1363: 186). Ardından İlhanlı emirlerinin intikamını almak amaciyla Emir Altacu ve Emir Timur komutasında bir ordu sevk etti.

\footnotetext{
${ }^{5}$ Kaynakların birçoğunda Türkan Hatun'un Selçuk-şâh ile evlilik yaptığı bilgisi verilirken Mecmau'l-Ensâb’ta Türkan Hatun'un evlendiği kişinin Muhammed-şâh b. Salgur-şâh olduğu ifade edilmektedir (Şebânkârê̂; 1363: 185). Aynı şekilde Yılmaz Öztuna, Salgom'un evli olduğu Muhammed-şâh’tan 1262 yılında annesiyle evlenebilmesi için ayrıldığını ifade etmektedir (Öztuna, 1989: 505).
} 
Bu orduya kardeşinin intikamını almak amacıyla Türkan Hatun'un kardeşi olan Yezd Atabegi Rükneddin Alâüddevle de katıldı (Benâketî, 1348: 409; Vassâf, 1346: 108; Şirâzî, 1310-1350: 63; Karakoç, 1998: 129). Türkan Hatun'un öldürülmesi, Fars bölgesinde yaşanacak yeni karışıklıkların başlangıcı oldu. Selçuk-şâh'ın siyasî tutumu, Salgurlular'ı kaosa sürüklediği gibi kendisinin de sonunu getirdi.

Emir Altacu, Moğol birlikleriyle ilerleyişi esnasında Selçuk-şâh'a elçi göndererek hatasını anlar ve özür dilerse Hülâgû Han ile arasında arabulucuk yapabileceğini iletti. Altacu, bu şekilde sulh yoluyla problemi çözmek isterken Selçuk-şâh, Altacu'nun elçilerini geri çevirdi (Vassâf, 1346: 109; Mîrhând, 1848: 45-46). Selçuk-şâh bu tavrryla kendisinden önceki atabeglerin yapmaya cesaret edemediğini yapmıştı. Kendisini emniyete almak isteyen Selçuk-şâh, Moğolların hızlı ilerleyişi karşısında Şirâz'dan kaçmak zorunda kaldı. Savunmasız kalan ahali ise Emir Mesud liderliğinde kadı ve şehrin ileri gelenleriyle ellerinde Kur'ân'larla Altacu'yu karşıladılar. Canını kurtarmak için kaçan Selçuk-şâh, Beglik Bey ve yakın adamlarıyla ilk olarak Hurşif dolaylarına çekildi. Daha sonra Kazerun yakınlannndaki Evliya Şeyh Mürşid Ebû İshak Kâzerûnî türbesine sığındı (Vassâf, 1346: 109; Reşîdüddîn, II, 1373: 936; Mîrhând, 1848: 46-47; Karakoç, 1998: 129). Selçuk-şâh, sığındığ1 türbede çaresiz beklemeye başladı. Moğol kuşatması karşısında türbede kalmalarının imkânsızlığını anlayan Beglik Bey, Selçuk-şâh'a kurtuluşu taahhüt ederek kaçmayı teklif etti (Mîrhând, 1848: 4749). Fakat Selçuk-şâh, bu teklifi kabul etmeyerek onun kaçmasına müsaade etti. Beglik, birkaç adamı ve hazineden aldığı bir miktar parayla kaçtı. Yezd Atabegi Alâüddevle ise onu takibe koyuldu. Takip esnasında atılan zehirli okla yaralanan Alaüddevle geri döndü ve birkaç gün sonra hayatını kaybetti. Türbede kuşatılan Selçuk-şâh ise kısa sürede esir alındı ve Sefid Kalesi’nin önüne götürüldü. Abiş ve Salgom Hatun'un Sefid Kalesi'nden serbest birakılmasından sonra da kale önünde öldürüldü (Mîrhând, 1848: 48-49; Vassâf, 1346: 110; Şîrâzî, 1310-1350: 64; Merçil, 1991: 107-108; Karakoç, 1998: 129).

Selçuk-şah'in naibe Türkan Hatun'un girişimiyle başlayan ve 7 ay süren saltanatı, 12 günlük kuşatmanın akabinde 1264'te Moğolların dahliyle son buldu (Gaffârî, 1343: 127; Vassâf, 1346: 110). ${ }^{6}$ Selçuk-şâh'ın icraatlarına bakıldığında onun sergilediği olumsuz tutum, İlhanlı hâkimiyetinin artırilmasina firsat verdi.

\section{Abiş Hatun'un Atabegliği ve Salgurlular'da İlhanlı Hâkimiyeti}

Selçuk-şâh'ın ortadan kaldırılmasından sonra Salgurlu hanedanında Atabeg II. Sa'd ve Türkan Hatun'un kızları Abiş ve Salgom hatunlar kaldı. Bunlar, anneleri Türkan Hatun'un öldürülmesiyle birlikte Sefid Kalesi'ne hapsedilmişlerdi (Reşidüddîn, II, 1373: 936; Benâketî, 1348: 409; Mîrhând, 1848: 47-49; Merçil,1991: 107-108; Sümer, 1988: 310). Kale komutan1, Atabeg Selçuk-şâh'a, Abiş ve Salgom Hatun'u hiçbir surette birakmayacağına dair yemin etmişti. Selçukşâh, Kâzerûn'da esir alındığı zaman hatunları serbest bırakması istenmiş lakin komutan yemininden dolayı bu isteği yerine getirmemişti. Bunun üzerine Selçuk-şâh kale önlerine getirildi ve onun emri doğrultusunda hatunlar serbest birakıldı (Karakoç, 1998: 129). Abiş Hatun, Sefid Kalesi'nden kurtulduktan sonra Salgurlu emirlerinin ve İlhanlı Hanlığı'nın onayını alarak 1264 y1lında atabeg ilan edildi. Adına hutbe okutulup, para bastırıldı (Reşidüddîn, II 1373: 936; Vassâf, 1346: 110; Gaffârî, 1343: 127; Şîrâzî, 1310-1350: 64).

Salgurlular'da Ebu Bekr b. Sa'd ve II. Sa'd'ın tüm erkek çocuklarının ölmesiyle oluşan siyasî boșluk, Abiș Hatun'un atabeyliğe getirilmesiyle giderilmiș oldu. Hatun'un doğum tarihi ve çocukluğu konusunda kaynaklarda detaylı bilgilere ulaşılamamaktadır. Onun hayatına dair ilk bilgi, 1259 yılında Hülâgû'nun oğlu Mengü Timur ile nişanlanmasıdır (Mîrhând, 1848: 49; Sümer, 1988:

\footnotetext{
${ }^{6}$ Selçuk-şâh'ın ölüm tarihi konusunda kaynaklarda farklılıklar zikredilmektedir. Tarih-i Cihan-ara'da Kasım-Aralık 1264 tarihi (Gaffârî, 1343: 127), Târih-i Vassâf da Mart-Nisan 1264 tarihi (Vassâf, 1346: 110), Tarih-i Güzide'de ise sadece 1264-1265 tarihi (Kazvînî, 1913:122) verilmektedir.
} 
310). 1259 yılında Emir Altacu'nun Şîrâz'da bulunduğu sırada Salgom Hatun, Atabeg Ebu Bekr'in yeğeni Muhammed-şâh ile evlendirildi. Abiş Hatun ise Hülâgû Han'ın oğlu Mengü Timur ile nişanland1. Moğol şehzadesiyle nişanlanan Abiş Hatun'a Basra hediye edildi. Abiş Hatun ve Mengü Timur'un nişan akdinin gerçekleştirilmesinden sonra Altacu, Hülâgû'nun yanına geri döndü (Reşîdüddîn II, 1373: 936; Merçil, 1991: 95).

Abiş Hatun, 1264 yllında tahta oturtulduğunda İlhanlı emirleri Selçuk-şâh'ı cezalandırarak Şîrâz'a döndü. Emir Timur'un askerleri Şîrâz halkının bir daha isyana teşebbüs etmemesi için şehirde katliam yapılmasını teklif etti. Lakin Altacu daha önce bağlllıklarını bildirmiş olmaları nedeniyle bu teklifi kabul etmedi. Altacu'nun, gerekli düzenlemeleri sağlayıp Hülâgû Han'ın yanına dönmesinden sonra (Mîrhând, 1848: 49-50; Vassâf, 1346:111; Merçil, 1991: 109) Şîrâz'da birakılan Abiş Hatun, idarî düzenlemelerde bulundu. Kendisine yakın emirlerden Gülce'yi, Naib-i Divan unvanıyla Atabeg vekili tayin etti (Vassâf, 1346: 113; Merçil, 1991: 129). Abiş Hatun'un atabegliği sırasında karşılaştı̆̆ı ilk olay, Kadı Şerefeddin İbrahim’in başlattığı isyandı. Kadı Şerefeddin İbrahim, Fars bölgesinin ileri gelenlerinden olup Horasan'a göç etmiş ve burada çok sayılda taraftar edinmişti. O, kendisinin ahir zaman mehdisi olduğuna inanan müritleriyle Şîrâz’’ ele geçirmek için harekete geçti. Abiş Hatun'un atabegliğe yeni gelişi ve tecrübesizliği, Kadı Şerefeddin'e isyan firsatı vermiş olmalıydı. İsyancı Şeyhin ilerleyişi üzerine Gülce, Moğol şahnesi Bastû ile birlikte harekete geçti. İki ordu, 1265 yılında Guvar Köprüsü civarında karşılaştı. Bu karşılaşma esnasında Seyyid'in kerametleri sıralanıp, görünmeyen toplulukların Kadı'ya yardım ettiği yönünde söylemlerde bulunuldu. Bu durum, Salgurlu askerlerinde kısa süreli tereddüte sebep oldu. Tüm keramet söylentilerine rağmen Şeyh İbrahim ve müritleri 1265 Nisan-Mayıs ayında Guvar Köprüsü yakınındaki mücadelede öldürüldü (Vassâf, 1346: 110-111; Şî̀âzî, 1310-1350: 64; Sümer, 1988: 311). Mirhând, ona bağlı olan cabillerin bazılar duah bir avuc tass kırntısı istediler, onu saştılar ve o tass parçalarmm her birinin žrh giymiş süvari olduğuna inandılar (Mirhând, 1848: 51-52) sözleriyle iddia edilen kerametlerin asılsızlığını vurgulamaktadır.

Fars bölgesinde büyük karışıklığa sebep olabilecek bir isyan Moğol ordusunun girişimiyle kısa sürede bastırıldı. Şîrâz'da yaşanan karışıklıkları duyan Hülâgû, Şîrâzlıların isyanı desteklediğini düşünerek oldukça öfkelendi. Çok sayıda askeri, Şîrâz'a sevk ederek Cengizhan'ın Maveraünnehir'de yaptığı gibi Fars bölgesinin yağmalanmasını ve herkesin öldürülmesini emretti. Fakat kısa süre sonra Şirâz halkının isyana müdahil olmadığı haberini alan Hülâgû, orduyu geri çevirdi (Mîrhând, 1848: 52-53; Vassâf, 1346: 112). Bu olay, Hülâgû'nun Fars bölgesinde yaşanacak karışıklıkta bölgedeki otoritesinin sarsılacağını düşündüğü ve bu düşünceyle hiçbir karışıklığa firsat vermek istemediği şeklinde değerlendirilebilir.

\subsection{Abiş Hatun'un Mengü Timur ile Evliliği ve Şîrâz'in Durumu}

Abiş Hatun, 1265 yılında Şeyh Şerefeddin isyanını bastırdıktan yani Şîrâz'da 1 yıl kaldıktan sonra Kirman melikesi olan anneannesi Yakut Türkan ve kız kardeşi Salgom ile itaatini yinelemek için Hülâgû Han'in huzuruna gitti. Bu ziyaret sırasında küçük yaşta olan Abiş Hatun ile Mengü Timur nikâhlandı. ${ }^{7}$ Abiş Hatun'un evlilik akdinin yapılmasının ardından daha önce Muhammed şah ile evlilik gerçekleştirmiş olan kız kardeşi Salgom da Yezd Atabegi Yusuf-şâh ile evlendi (Reşidüddin, II, 1373: 936; Benâketî, 1348: 409; Kazvînî, 1913: 122; Merçil, 1991: 110-111). Evlilik akdinin ardından Hülâgû'nun ölümüyle İlhanlı tahtına oturan Abaka Han, Abiş Hatun'a vekil olarak Soğuncak Noyan'1 Fars bölgesine vali tayin etti (Spuler, 2011: 377; Uygur, 2019: 221-222).

Abiş Hatun, atabeg tayin edildiği zaman devleti idare edebilecek siyasî olgunlukta değildi (Üçok, 2011: 162). Bu nedenle Salgur Atabegliği yönetimi üzerinde tam olarak nüfuz sahibi olamadi. İlhanlıların Salgurlular'a müdahalesine ve sık sık İlhanlı valisi tayin edilmesine tepki gösteremedi.

\footnotetext{
${ }^{7}$ Bu nikâhlanma, küçük yaşta olan hatunun 12-13 yaşına gelmesiyle tamamlandı. Mengü Timur da kendisinden 6 yaş büyüktü. Evlilikten 10 yıl sonra Mengü Timur’un ölümüyle dul kaldı (Öztuna, 1989: 505).
} 
Abaka Han, otorite zafiyetinden kaynaklı yaşanan karışıklıkların devam etmesi üzerine 1266 yılında emirlerinden Bitikçi ve Timur'u Fars bölgesinin yıllık haracını almak amacıyla görevlendirdi (Mîrhând, 1848: 53; Vassâf, 1346: 112). Bu emirlerin de düzeni sağlamakta zorlanması üzerine Angiyanû adlı emirini Şîrâz'a naib tayin etti (667/1268-1269). Angiyanû, Şîrâz'da nüfuz elde etme ve servetini artırma yoluna gitti. Ayrıca Abiş Hatun'un en büyük destekçisi Gülce'yi hiçbir gerekçe sunmadan hapsetti. Hatunun yakınları Gülce'yi kurtarmak için girişimde bulundu. Fakat Angiyanû, Gülce'nin kesik başını sarayın surlarından atarak onlara cevap verdi. Naibini kurtaramayan Abiş, Angiyanû ile temasa geçerek yapılanların hesabını sordu. Savunmaya geçen İlhanlı naibi, Gülce'yi Abaka Han'in emriyle öldürdügünü söyledi (Mîrhând, 1848: 53; Vassâf, 1346: 112; Şîrâzî, 13101350: 65; Merçil, 1991: 112). Verilen cevap karşısında geri adım atmak zorunda kalan Hatun, Angiyanû'nun Şîrâz'da sergilediği tutumdan dolayı Şîrâz ileri gelenleriyle anlaştı ve Abaka Han ile temasa geçti. Angiyanu'nun sultanlık arzusuyla ayaklanmaya hazırlandığını ve Fars memleketini harap ettiğini söyleyerek şikâyetlerini sıraladı. Naibliği sırasında adına para bastırmasının delil olarak sunulması üzerine Angiyanu Şîrâz naibliğinden azledildi ve 1271/1272 yllında yerine Soğuncak ${ }^{8}$ tayin edildi (Vassâf, 1346: 112: Şîrâzî, 1310-1350: 65). Vassâf'n kayıtlarından anlaşıldı̆̆1 üzere İlhanlı emirleri tayin edildiğinde Abiş Hatun Şîrâz'da bulunmaktaydı. Fakat 1268/1269 yılında Angiyanû'nun naibliğine kadar yaşanan olaylarda doğrudan Abiş Hatun'un adı zikredilmemektedir. $\mathrm{Bu}$ da onun atabegliğinin göstermelik olduğu ve yönetimden uzak tutulmak istendiği izlenimini oluşturmaktadır.

1271/1272 y1lında Şîrâz’a gönderilen ve İlhanlı valisi olarak yönetime hâkim olan Soğuncak, Fars bölgesine yeni bir mali uygulama getirdi. Soğuncak, vergi düzenlemesi yaptı ve 1273 yll başından itibaren devlet toprağını mukataa yoluyla dağıtmaya başladı. Ardından devlet yönetiminde düzenlemeler yapan Noyan, bölgeye doğrudan İlhanlı hanına bağlı idareciler tayin etti. Noyan, sadakatine inandığı Seyyid İmadeddin'i' Salgurlu Atabegliğinin bir kısmına naib tayin etti. Ayrıca Muhammed Beg, Tutyak ve Bulûgân'1 Fars bölgesi şahneliğine getirdi. Soğuncak Noyan, 1273 yılında Hurşif dolaylarında yaptığ başarısız deniz savaşı sonrasında iki yıllık naibliğinin ardından ödenmesi gereken vergiyi topladı ve Abiş Hatun ile birlikte İlhanlı Hanı'nın yanına gitti (Vassâf, 1346: 113-114; Şîrâzî, 1310-1350: 65; Sümer, 1988: 311; Merçil, 1991: 113).

Bu ziyaret sırasında Abiş Hatun ve Mengü Timur'un daha önce yapılan nikâh akdi, evlilikle tamamlandı ve karşılıklı hediyeler takdim edildi. Ayrıca Abiş Hatun'un, kendisine verilen mihir karşllı̆ı̆nda yüklü miktarda çeyiz getirmesine karar verildi. Abiş Hatun'dan çeyiz olarak Firuzî ve Nevruzî bahçeleriyle Hân melikî çarşısının 1/4'ü, Şîrâz'daki büyük arazilerin gelirlerinin 1/6'sından her yıl 70 bin dinarın hanlığa göndermesi istendi. Türkan Hatun'un ölümüyle Moğol tahakkümüne maruz kalan Salgurlular, bu evlilikle toprakların büyük bir kısmının gelirini İlhanlılara devretmiş oldu. Çeyiz olarak istenenlerden İlhanlıların Salgurlu Atabegliğinin emlakı üzerinde kalıcı bir hâkimiyet kurmayı arzuladıkları anlaşılmaktadır. Ayrıca evlilik akdinin tamamlanmasından sonra akrabalığa istinaden İlhanlılar, Salgurlu devlet yönetimine daha fazla müdahil oldu. Fars Atabegliği'nde İlhanlı şahneleri ve han tarafindan tayin edilen valilerin nüfuzu artt1 (Vassâf, 1346: 115; Merçil, 1991: 112; Üçok, 2011: 162). Tarih boyunca birçok devlet adam1, siyasî çıkarları doğrultusunda evlilikler gerçekleştirmiştir. Mengü Timur'un doğum tarihi (1256) (Öztuna, 1989: 505) dikkate alındığında bu evliliğin de devletlerin menfaatleri doğrultusunda yapılmıs siyasî bir evlilikten ibaret olduğu anlaşılmaktadır. Zira İlhanlılar, yapılan evlilik sayesinde bölgede ve devlet üzerinde kontrollerini sürdürecek ve yönetime doğrudan müdahil olma hakkını elde edeceklerdi (Spuler, 2011: 162; Beyânî, 2015: 13).

İlhanlı hanedanıyla akrabalık kurmuş olan Abiş Hatun, Salgurlu Atabegliğinin lideriydi. Fakat siyasî ve idarî anlamda hiçbir söz hakkı bulunmuyordu. Evlilik için Tebriz’e giden Abiş Hatun,

\footnotetext{
${ }^{8}$ Soğuncak adı Suncak olarak da geçmektedir (Yuvalı, 2017: 328; Dayı, 2020: 193, 262-263).

9 Şîrâznâme’de Nasıreddîn Ömer Beyzâvî ismi zikredilmektedir (Şîrâzî, 1310-1350: 65).
} 
10 yıl süreyle burada kaldı. Bu süreçte İlhanlı memurlarının kontrolü altına giren Fars bölgesinde emirler arasındaki anlaşmazlık had safhaya ulaştı. Târîh-i Vassâf da nakledilen bilgiye göre emirler birbirlerine karşllkklı olarak öfke dolu mektuplar göndermekte, taraftar edinmek için rüşvetler ve hediyeler dağıtmaktaydılar. Ayrıca bu süreçte ahaliyi keyfi vergilerle ağır malî yük altına da sokmuşlardı. 1277/1278 y1lında yaşanan iç çatıșmalar ve mali soygunlar, Fars bölgesinin tamamen harap duruma gelmesine neden oldu (Vassâf, 1346: 115-117; Merçil, 1991: 113-114). Abaka Han, yaşanan karışıklıklara son vermek ve kalan haracı tahsil etmek için Soğuncak'1 1279/1280 y1lında tekrar Şîrâz'a gönderdi. Salgurlu idaresinde yeniden düzenlemelerde bulunan Soğuncak, Hoca Nizâmeddîn'i vezirlik makamına, Mevlana Kadı'l Kudat Seyyid Nasr-mille ${ }^{10}$ ve Rükneddin Ebu'l Yahya'yı Fars baş kadılı̆̆na getirdi. Kendinden önceki emirlerin malî soygunlarını durdurarak maliyeyi kontrol altına aldı (Vassâf, 1346: 118-120; Şirâzî, 1310-1350: 66; Merçil, 1991: 115).

\subsection{Abiş Hatun'un Şîrâz’a Gönderilmesi ve Seyyid İmadeddin ile Anlaşmazlığı}

Abiş Hatun'un Şîrâz’a dönüş vaktine kadar bölgede İlhanlılar tarafindan tayin edilen Seyyid İmadeddin, Bulugan, Tagaçar ve Taş Mengü etkili oldu (Şîrâzî, 1310-1350: 67; Uygur, 2019: 230). 1282 yılı Nisan ayına gelindiğinde ise Abaka Han ve Mengü Timur art arda hayatını kaybetti. Emirler arasındaki anlaşmazlıklar ve karışıklıklar aynı şekilde devam etti. Abaka'nın ardından hanlık makamına getirilen Ahmed Tekudar, Şîrâz'da sükûnetin bir türlü sağlanamaması üzerine yakın emiri Taş Mengü’yü Şirâz'a gönderdi. Taş Mengü’nün 1 yıllık naibliğinden sonra 1284 yllina gelindiğinde Atabeg Abiş’i de tekrar Şîrâz’a göndermek zorunda kaldı (Merçil, 1991: 116-117; Uygur, 2019: 230231). ${ }^{11}$ Atabeg Abiş, uzun süre sonra kavuştuğu Salgurlu tahtında yine müstakil hareket edemedi, Taş Mengü kontrolünde liderlik yaptı. Şîrâz halkı ise Hatun'un gelişine oldukça mutlu oldu, çarşı ve mahalleleri süsleyerek sevinç gösterisinde bulundu. Abiş Hatun, uzun süre sonra büyük umutlarla Salgurlu tahtına oturtuldu. Eskiye nazaran daha tecrübeli olan Hatun, Salgurlu Atabegliğini eski gücüne kavuşturmak için düzenlemeler yaptı. Hanedan üyesi Celaleddin Erkan b. Muhammed Zengi'yi naiblik ve Hoca Nizameddin Ebu Bekr'i vezirlik makamına getirdi (Vassâf, 1346: 120-124; Şîrâzî, 1310-1350: 68) Hatun tarafindan güvenilen kişilerin idarî kadroya atanması, atabeglig üzerindeki İlhanlı hâkimiyetinin kırılmasına yönelik girişimler olarak değerlendirilebilir.

Atabeg Abiş, ikinci kez tahta çıktığında da Moğolların maddî talepleri devam etmekteydi. Fakat Abiş Hatun, müstakil olma arzusuyla hareket etti ve hanedan topraklarını genişletmek için girişimlerde bulundu. Devletin menfaati için çalışan vezir Hoca Nizâmeddîn, Şîrâz'a dönüş öncesinde Atabeg Abiş'e, Salgurlu hanedanına ait birçok emlakın İlhanlı tasarrufunda olduğunu ve bunlardan bir kısmının tasarrufunu tekrar hanedanın kontrolüne almasını tavsiye etti. Hatun, Şîrâz'a dönüşünde çeyiz ve diğer şekillerde İlhanlılara bırakılan Salgurlu emlakının geri verilmesi için Ahmed Tekûdar'dan yarlıg almayı başardı. Han'ın onayyyla her vilayetten dilediği emlakı, Hassa arazisi adıyla hanedan mülküne dâhil etti ve kendisine güvendiği kişileri bu yerlere memur tayin etti (Vassâf: 1346: 124; Beyânî, 2015: 10). Abiş Hatun, atabeg emlakında düzenlemeler yaparak doğrudan memleket işlerine katk1 sağlamaya ve otoritesini kurmaya gayret etti (Şîrâzî, 1310-1350: 68). Şirin Beyânî ise Abiş Hatun'un atabeglig emlakını arttırdığını lakin Fars bölgesinin gelişmesi için gerekli olan imar faaliyeti noktasında fazla bir şey yapmadığını ifade etmektedir (Beyânî, 2015: 10).

Abiş Hatun'un atabegliği halk nezdinde sevinçle karşılanırken idareciler arasında iktidar kavgalarına sebep oldu. Hatun'un, İlhanlı Hanedan üyesi olmasından aldı̆̆ cesaretle atabegliğini sürdürmeye çalıştı̆̆ bu dönemde Ahmed Tekûdar öldü ve yerini Argun Han aldı. İlk defa Abaka Han tarafından Şîrâz’a vezir tayin edilen Seyyid İmadeddin ise anlaşmazlık yaşadığı vezir

${ }^{10}$ Nâsırüddin Ebû Saîd Abdullah b. Ömer b. Muhammed el-Beyzâvî ya da diğer adıyla Kâdî Beyzâvî’dir (Şîrâzî, 13101350: 65; Ar1c1, 2017: 44 vd).

${ }^{11}$ Şîrâznâme'de Abiş Hatun'un Abaka Han'ın hükmüyle Şîrâz'a gönderildiği bildirilse de (Şîrâzî, 1310-1350: 68) Abaka Han'ın saltanatı 1 Nisan 1282 tarihinde Hemedan'da ölümüyle son bulmuştu (Spuler, 2011: 88). 
Nizameddin'i ve Abiş Hatun'u bertaraf etmek istiyordu. Han değişikliğinden faydalanan İmadeddin, emir Buka'nın desteğiyle Argun'un huzuruna çıtı ve Abiş Hatun'la vezirini şikâyet etti (1284). Argun Han kendisinden hoşnut olduğu Seyyid İmadeddin’i geniş yetkilerle donatarak Şîrâz'a gönderdi. Ayrıca, İlhanlı emirlerinden Odamış ve Çerik'i Şîrâz şahnesi, Hoca Kıvameddin Buhari'yi Şîrâz memuru, Hoca Seyfeddin Yusufu da istifa makamına getirdi. Son olarak Atabeg Abiş Hatun'un azline ve huzuruna çıkmasına dair bir ferman verdi. Argun Han'ın fermanıyla Abiş Hatun'un atabegliğine son verilmiş oldu (Vassâf, 1346: 124-125).

Atabeg Abiş Hatun ve çevresindeki emirler, Argun Han'ın aldığ kararlardan ve vezirlik makamına Seyyid İmadeddin'in tayin edilmesinden rahatsız oldular. 2 Aralık 1284'te Şirâz'a gelen Seyyid İmadeddin ise Abiş Hatun'u görmezden gelerek yönetime el koydu ve Hoca Ebu Bekir adlı Şîrâz şahnesini öldürdü. Fars bölgesinin maliyesini kontrol altına alarak ödenmesi gereken vergilerin hesaplarını incelemeye aldı (Şîrâzî, 1310-1350: 69; Vassâf, 1346: 125). Ayrıca Abiş Hatun'a Argun Han'ın huzuruna gitmesi gerektiği haberini gönderdi. Akıbeti konusunda tereddüt yaşayan Abiş, Han'ın bu emrine itaatsizlik göstererek Şîrâz'da kaldı. Seyyid İmadeddin, Şîrâz'a geldiğinde doğrudan Atabeg Abiş'in huzuruna gitmemişti. Ayrıca Salgurlular'da tek bir idareci gibi hareket etmekteydi. Bu şekilde hatunu göz ardı eden bir tutum sergilemesi, ona karşı hoşnutsuzluğun artmasına sebep oldu. Atabeg Abiş ve taraftarları, İmameddin tarafindan düzenlenen ziyafete ve bayram namazına katılmadılar. Hatun bu tavrıyla Seyyid İmadeddin'in naibliğini tanımadığını açık olarak göstermekteydi. Naib İmadeddin'in tutumu Atabeg Abiş'in öfkeli konuşmalarına ve aleyhine işbirliği yapmasına sebep oldu. Ondan kurtulmak için harekete geçen Abiş Hatun ve emirleri, istişareleri neticesinde Seyyid İmadeddin'in öldürülmesine karar verdi. Bunu meşru bir zemine oturtmak için de devlet adamlarının şahitliğinde fetva hazırladılar. Hatun, canını emniyet altına almak için girişimde bulundu ve olayların bilgisi dâhilinde gerçekleştiğinin bilinmemesi kaydıyla İmadeddin'e yapılacaklara onay verdi (Vassâf, 1346: 125).

Atabeg Abiş, Seyyid İmadeddin ile nüfuz mücadelesi yaşadığ1 bu süreçte Nikûdâr ordularının Kirman sınırlarına ilerlediği haberini aldı. Savunmaya geçen İmadeddin, Salgurlu lideri Abiş’i kurtarmak için Istahr Kalesi’ne gitmesi gerektiğini bildirdi. Abiş, anlaşmazlık yaşadığ1 İmadeddin'in bu girişimiyle kendisini hapsetmek istediğini düşünerek öfkelendi. Lakin bunu yansıtmayarak daha önce aldıkları kararı uygulamaya koydu. Hatun, sarayına giden İmadeddin'in arkasından birkaç adamını gönderdi ve huzuruna çıkmasını istedi. Bunu kabul etmeyen İmadeddin, zorla ele geçirilerek öldürüldü (Vassâf, 1346: 126-127; Gaffârî, 1343: 127; Reşîdüddîn, 2013: 156; Merçil, 1991: 119).

Seyyid İmadeddin'in ardından onun yanında yer alanların ortadan kaldırılmasına devam edildi. Atabeg Abiş, Seyyid'in amcasının oğlu olan Cemâleddin Muhammed'i saraya çağırdı. Bu şahıs daha önce Abiş Hatun'un ihsanlarına nail olduğu için sarayda öldürülme kaygısı taşımıyordu. Atabeg Abiş'in emirlerinden bir grup, gece karanlığında Cemâleddin Muhammed'i Şirâz'in dışına çıkardı ve beklemediği bir anda öldürdü. Cesedini de bulunamaması için bir kuyuya attılar ve kendisinin ölüm korkusuyla atabeglikten kaçtığı yönünde söylenti çıkardılar. Ayrıca İmadeddin'in öldürülmesini meşru kilmak ve oluşabilecek tepkiyi en aza indirmek amaciyla naibin Şîrâz halkına zulmettiğini ve bu nedenle ortadan kaldırıldığını ilan ettiler. Seyyid İmadeddin'in ardından Şirâzz halk1, birbirlerini tebrik ederek davullar ve bayraklarla eğlence tertip etti. Müstevfi Hoca Seyfeddin ise İlhanlı memuru sıfatıyla bir yandan Salgurlu Atabegliğindeki karışıklığı gidermek için çalışırken diğer yandan İmadeddin'in öldürülmesine dahil olanların listesini hazırladı (Vassâf, 1346: 126-127; Üçok, 2011: 165).

Argun Han'ın desteğini almış güçlü bir rakibin bertaraf edilmesiyle Fars bölgesinin kontrolü tekrar Abiş Hatun'a geçti. Fakat Şirâz'da istenilen düzen bir türlü sağlanamadı, Salgurlu Atabegliği'nin çöküşünün önüne geçilemedi. Şîrâz, Atabeg Abiş’in son dönemlerinde siyasî ve askerî kargaşanın yanı sıra büyük bir doğal afete de maruz kaldı. Seyyid İmadeddin'in ölümünden 
sonra Fars bölgesine 3 yıl boyunca yağmur yağmadı. Kuraklığın etkisiyle çiftçiler toprağını işleyemedi ve büyük bir kıtlık yaşandı. Seyyid’in naibliği zamanında bir kile buğday 100 Şîrâz dinarı değerindeyken, kıtlık zamanında şayet bulunabilirse 1.200 dinar ve daha fazla fiyatlarla satıldı. Yiyecek bulmakta zorlanan ahali, hayatta kalabilmek için bahar mevsiminde çekirge yemek, sonbaharda ise kesilen hayvanların kanını içmek zorunda kalmıștı. 3 yıl süren kıtlıkta Fars vilayetlerinde çok sayıda insan hayatını kaybetti (Vassâf, 1346: 128; Şîrâzî, 1310-1350: 70; Merçil, 1991: 120). Bu süreçte kuraklığın yanı sıra çekirge istilası da ahaliyi zor durumda biraktı. Kuraklıkla mücadele eden halkın ekili arazileri çekirge istilasına maruz kalmıştı. Ahali yaşadığı zorlukları, Seyyid İmadeddin'in öldürülmesi nedeniyle Fars bölgesinin Allah'ın gazabına uğradığı sözleriyle ifade etmişti (Şîrâzî, 1310-1350: 70; Uygur, 2019: 239).

\subsection{Abiş Hatun'un Argun Han Tarafından Yargılanması ve Ölümü}

Seyyid İmadeddin'in ölümünden sonra oğlu, Argun Han'ın yanına giderek tüm gelişmeleri anlattı. Bunun üzerine Argun Han, Abiş Hatun ve olayın içerisinde yer alanların huzuruna çıkması emrini verdi. Ayrıca atabegliği süresince Abiş Hatun'u himaye eden Mengü Timur'un annesi Olcay Hatun'a Abiş Hatun'un isyan yolunu seçtiği haberini gönderdi. Olcay Hatun bu haber karşısında Abiş Hatun'un affını istediği gibi yargılama sürecinde mahkemede bulunacağını ve hak ettiği cezayı almasını kabul ettiğini bildirdi. Olcay Hatun, bir yandan Han'a karşı sulh yolunu izlemeye çalışırken diğer yandan gizlice Abiş Hatun'a bir elçi gönderdi ve kendisini uyararak en kısa sürede Argun Han'ın huzuruna gitmesini istedi (Vassâf, 1346: 128; Merçil,1991: 120).

Atabeg Abiş, Olcay Hatun'un uyarılarını dikkate almayarak elçileri hediyeler ve eğlencelerle meşgul etti. Ayrıca yanında yer almasını istediği Moğol emirlerine kıymetli hediyeler gönderdi. Hatun, Moğol emirlerinin desteğini alarak cezalandırılmasının önüne geçmeyi arzulamaktaydı. Yaşananlara oldukça öfkelenen ve olaya dahil olanları huzuruna isteyen Argun Han, vakit kaybetmeden Hüsameddin Kazvînî12, Toluday ve Çuyurğutay'1 Şîrâz'a gönderdi. Emirler, Seyyid İmadeddin'in ölümünü ve Salgurlu maliyesinin durumunu incelemekle görevlendirildi. Şîrâz’a ulaşan emirler, Fars bölgesinin maliyesini kontrol altına aldı ve Abiş Hatun'un atabegliğten azledildiğini bildirdi. Emirlerin sorgulama yaptığ1 ve Abiş Hatun'un kurtuluş ümidiyle beklediği sırada Kenân Aktâcî, derhal tevkif edilmesinin emredildiği yeni bir fermanla Şîrâz'a geldi. Han'in son hükmüyle Atabeg Abiş, Celaleddin Erkân ve birkaç emir Tebriz'e gitmeleri için yola çıkarıldı. Atabeg Abiş’in otağı ilk olarak Şîrâz'dan Cihâd-âbâd'a nakledildi. 1 hafta süren hazırlıkların tamamlanmasının akabinde de Tebriz'e götürüldüler (Vassâf, 1346: 128-129; Şîrâzî, 1310-1350: 70; Merçil, 1991: 121).

Tebriz'e ulaştıkları zaman Abiş Hatun'a Han gelini olması sebebiyle hürmetle yaklaşılırken, diğerleri Tebriz çarşılarında gezdirilerek tahkir ettirildi. Hatun'un Han gelini olması, bu şekilde bir hakarete uğramasına engel olmuşsa da Abiş Hatun, Argun Han tarafindan huzura kabul edilmedi. Han ile görüşme imkânı elde edemeyen Hatun, yargılama sürecinde etkili olan emir Buka'nın huzuruna gitti. Buka, Moğol âdetince Hatun'u karşılamak için çadırından çıktı ve önünde diz çöktü. Şîrâz'da müstakil atabeglik için girişimlerde bulunan Abiş Hatun, Tebriz'de bulunduğu süre içerisinde canını kurtarabilmek için alçak gönüllülükle hareket etti (Vassâf, 1346: 129).

Fars Atabegi Abiş ve diğer emirlerin yargılama süreci, Tebriz’e ulaştıktan bir gün sonra başladı (Reşîdüddîn II, 1373: 1161). Mahkeme vakti geldiğinde Olcay Hatun'un girişimi ve hanedan üyesi olması sebebiyle Abiş Hatun, halkın gözü önünde yargılanmadı. Mahkemeye ilk olarak Celaleddin Erkân, ardından da divan görevlilerinden Kıvâmeddîn Buhârî, Seyfeddîn Yûsuf ve Şemseddîn Hüseyin getirildiler. Sorgulama esnasında emirlere 70 değnek vurulduysa da hiç birisi konuşmadı. Celaleddin Erkân'ın yargılaması başlamadan önce Abiş Hatun ona haber göndererek hiçbir şekilde konuşmamasını istemişti. Fakat Celaleddin Erkân, üçüncü sopa vurulduğunda can

\footnotetext{
12 Şîrâznâme’de Şîrâz’a gönderilen emirin adı Hüsam Kazvînî olarak zikredilmektedir (Şîrâzî, 1310-1350: 70).
} 
acısıyla Abiş Hatun ile iş birliği yaptıklarını, onun emri doğrultusunda Seyyid İmadeddin’i öldürdüklerini söyledi. Öldürülme korkusu yaşayan diğer memurlar, Celaleddin Erkân'ın korkuyla konuştuğunu söylese de Argun Han onlara itibar etmedi (Vassâf, 1346: 129-130; Merçil, 1991: 121). Emirlerin yargılamaları tamamlandıktan sonra Atabeg Abiş ile hareket eden emirler yüklü miktarda para cezasına çarptırıldılar. Bu cezaya göre Salgurlu Atabegliğinin ödemesi gereken haracın kalanı önceki yıllara göre artırılarak ödenecekti. Ayrıca Seyyid İmadeddin'in çocuklarına 50 tümen (500 bin dinar) ve Cemaleddin Muhammed'in çocuklarına ise 20 tümen (200 bin dinar) verilecekti (Vassâf, 1346: 130; Merçil, 1991: 122). Yargılama sonunda Salgurlu hanedan üyesi ve Abiş Hatun'a yakın konumda olan Celaleddin Erkân suçunun sabit olması nedeniyle öldürüldü (Şîrâzî, 1310-1350: 71; Reşîüüdîn, 2013: 156). ${ }^{13}$

Abiş Hatun'un saltanatı, emirlerin yargılama süreciyle son buldu. Hanedan üyesi olduğu için kendisine hiçbir ceza verilmeyen Atabeg Abiş, yeni bir karışıklığa sebep olabilme ihtimalinden dolayı bir süre daha Tebriz'de tutuldu. Tebriz'de göz hapsinde tutulan Hatun, yargılamadan bir yıl sonra hastalandı ve Cerendâb’ta hayatını kaybetti (29 Aralık 1286/11 Zilkade 685). Müslüman ve dindar bir hatun olarak tasvir edilen Atabeg Abiş, Mengü Timur ile evli olmasından kaynaklı olarak Moğol adetlerine göre altın ve gümüş kaplarla Tebriz yakınlarındaki Çerendâb’a defnedildi. Moğol kontrolünde geçen 22 yıllık saltanatı, bu şekilde son buldu. Kendisi Salgurlular'ın son atabegi olup onun ölümüyle Şîrâz merkezli Salgurlu Atabegliği de sona erdi. Ölüm haberi Şîrâz’a ulaştığında Salgurlu hanedanına her daim bağllık gösteren Şîrâz ahalisi büyük üzüntü yaşadı. Feryat edip, siyahlar giyerek, cami ve mahfillerde 3 gün boyunca yas tuttular (Vassâf, 1346: 130-131; Karakoç, 1998: 129-130; Mirhând, 1848: 53). Müellifler, Abiş Hatun'un yaşı konusunda net bir bilgi vermezken B. Spuler, Atabegliğe geldiği zaman çocuk yaşta olan Abiş Hatun'un 1286/1287 yllında öldüğünde henüz 22 yaşında olduğunu ifade etmektedir (Spuler, 2011: 162). Abiş Hatun'un ardından mirası, vasiyeti gereği dört kısma ayrıldı. Hülâgû Han'ın Mengü Timur'la nişanlanmasından dolayı kendisine verdiği dinar, emlak ve arazilerden elde edilen verginin 1/6's1 da aynı şekilde varisleri arasında taksim edildi. İki kısmı kızları Kerducin ve Algancı'ya, bir kısmı azatlıları ve kölelerine, bir kısmı da eşi Mengü Timur'un oğlu Tâycû'ya bırakıldı (Vassâf, 1346: 130131).

Abiş Hatun'un Çerendâb'da bulunan naaşı, bir süre sonra kııı Kerducin tarafindan Şîrâz'a nakledildi ve Makber-i Abiş adıyla bilenen Abiş Hatun ribatına defnedildi (Mîrhând, 1848: 53; Merçil, 1991: 123). ${ }^{14}$ Sa'di Şîrâzî, Salgurlu Atabegliği’nde önemli bir konuma sahip olan Abiş Hatun ve onun iktidarına övgüde bulunduğu bir methiye kaleme almıştı;

Feleğin bu kadar vakar ve temkini, ayın ve güneşin bu kadar parltısı olamaz.

Sabâ rüzgârı senin ayağının toprağı üzerinden geçse, onun eteklerinin misk kokusuyla dolması şaşılacak bir șey değildir.

Senin saltanat tacının incilerinden bir tanesi bile Ülker yıldızının manzumesinde bulunamaz.

Bu hanedanın saltanatı daim olsun, çünkü bu daim oldukça dine bir zarar ulaşmaz.

Senin hükmünden baş çeviren insan kadar dünyada talihsiz ve miskin kimse yoktur,

Senin düşmanının kalbi bir fil ayağının altında kalmış gibi ezilmiştir... (Üçok, 2011: 170).

\section{Atabeg Abiş Hatun Sonrası Fars Bölgesinin Durumu}

Abiş Hatun sonrası İlhanlı hâkimiyetine giren Fars bölgesi, nakillerden anlaşılacağı üzere sık sık yönetici değişikliklerine ve idareciler arasında iktidar mücadelelerine sahne oldu. Abiş Hatun'un ardından kızı Kerducin bir süreliğine onun varisi olarak kabul edildi. Atabeglik sarayında bir süre daha nevbet çalınmaya ve divan toplantıları düzenlenmeye devam edildi (Reşîüddîn, II, 1373: 937).

\footnotetext{
${ }^{13}$ Reşîdüddîn Fazlullah'1n nakillerine göre Argun Han, 21 Eylül 1285 tarihinde Tebriz'e ulaştı, ardından Arran'a yöneldi ve Abiş Hatun'u burada yargıladı. Bilgi için bk. (Reşîüuddîn, 2013: 156).

14 Müellifler tarafindan Atabek Abiş’in, Türkan Hatun'un oğlu Atabeg Muhammed adına inşa ettirdiği Adûdiye Medresesine defnedildiği de bildirilmektedir (Reşî̀üddîn, II, 1373: 937; Benâketî, 1348: 409; Üçok, 2011: 167).
} 
Abiş Hatun'un ölümünden sonra yargilamadan kurtulan Salgurlu emirleri, bir süre daha Tebriz'de tutuldular ve İlhanlı kontrolü altında varlıklarını devam ettirdiler. Geri dönmek için uygun vakti bekleyen emirler, İlhanlı Hanı nezdinde nüfuz sahibi olan Togan Kûhistânî ile iş birliği yaptılar. Togan'ın aracilı̆̆yla Salgurlular'ın biriken haracını ve 500 tümen (5 bin dinar) ödemeyi taahhüt ettiler. Bu teklifin Argun Han tarafindan kabul edilmesiyle Togan Kûhistânî Fars bölgesine vali tayin edildi. Ayrıca Fahreddin Mübarekşâh'a Bitikçi unvanı verilerek emir Cuşî ile birlikte sorunların çözülmesi ve malların tahsili için Şîrâz'a gönderildi. Şîrâz emirlerinin de içinde bulunduğu bu heyet, Fars sınırına yaklaştığı sırada Kıvâmeddin Buharî vefat etti. Hoca Şemseddin Hüseyin, Seyfeddin Yûsuf ve Nizameddin Ebu Bekr ise İlhanlı memurlarıyla Şîrâz'a ulaştı. Fahreddin Mübarekşâh, sükûneti sağlayabilmek için karışıklığa sebep olan insanları cezalandırdı. Bu süreçte Şîrâz'da masrafların karşılanması ve biriken borçların tahsili konusunda ciddi sıkıntılarla karşılaşıldı. Salgurlular'ın son döneminde emirler arasında yaşanan nüfuz mücadelesi ve uzun süren kitlığın ahaliye büyük sıkıntı yaşattığı anlaşılmaktadır. Taahhüt edilen paranın tahsilinde İlhanlılara verecek parası ve malı kalmayan ahali, Cuşî ve Sarban adlı Moğol memurlarının zulmüne maruz kaldı. Vadedilen 5 bin dinarın toparlanamaması ve maddî sıkıntıların çözüme kavuşturulamaması nedeniyle Cuşi, Şîrâz'dan ayrılma kararı aldı. Fahreddin Mübârekşâh'ı ise kalan paranın tahsili için Şîrâz'da birakarak İlhanlı Hanı'nın huzuruna gitti (Vassâf, 1346: 131).

S1k sık idareci değişikliğinin yaşandığ1 Fars bölgesine Togan Kûhistânî’nin ardından Sâdüddevle vali tayin edildi. O da Togan gibi doğrudan bölgeye gitmedi. 1287/1288 y1lında Cuşi, Şemsüd-devle b. Mecdûddevle ve İzzeddin Muzaffer Amîd adlı memurlarını Fars bölgesinin sorunlarını çözmekle görevlendirdi (Vassâf, 1346: 131; Şîrâzî, 1310-1350: 71; Spuler, 2011: 377). Tekrar Şîrâz’a gelen Cuşî, görevi süresince sert bir tutum içerisinde oldu. Şîrâz'da ilk olarak ödenmesi gereken haracı topladı, daha sonra karışıklıkları gidermeye çalıştı. Cuşî, Fahreddin Mübarekşah, Mecdeddin Rûmî, Hoca Şemseddin Hüseyin ve oğullarını cezalandırdı. Salgurlu devlet erkânından Hoca Seyfeddin Yusuf ve Hoca Nizameddin Ebu Bekr ise 100 tümen ve servetlerinden yüklü bir meblağı vererek canlarını kurtarmayı başardılar. Abiş Hatun'un ölümü ve Salgurlu hanedanının ortadan kalkmasıyla tamamen İlhanlı hâkimiyetine giren Şîrâz'da tüm ahaliye oldukça sert muamele yapıldı. Cușî, tahsilat sırasında insanları öldürmekten, gasp ve yağma yapmaktan çekinmemekteydi. Tamamen İlhanlılara tabi hale gelen Fars bölgesinde sebepsiz şekilde insanların malları müsadere edildi ve beratlar yazılarak ödenmesi gereken vergiler artırıldı. Şîrâz ileri gelenlerinden Mecdeddin Semerkandî’nin biriktirdiği ve yakınlarından birisinin evinde gizlediği 12 tümene (120 bin dinar) el konuldu. Cuşînin Şîrâz'daki icraatları bunlarla kalmadı. Zira O, yakın adamlarını Fars vilayetlerine göndererek her vilayetin emlakına dair bir liste oluşturmalarını emretti. Bütün köyler, bahçeler, tarlalar, su değirmenleri yani tüm araziler, üzerinde bulunanlarla kayıt altına alındı. Vassâfın verdiği bilgiye göre kayıt altına alınanlar arasında söğüt ve çınar gibi meyve vermeyen ağaçlar dahi bulunmaktaydı. Cuşi’nin emri doğrultusunda Salgurlular'ın son büyük lideri Atabeg Sa'd Ebu Bekr zamanından itibaren Fars bölgesinin tamamını kapsayan bir liste düzenlendi. Sayımin tamamlanmasindan sonra Salgurlulara hizmet eden ve yargilamadan kurtulan devlet adamları Hoca Seyfeddin ve Hoca Nizameddin, Han'ın emriyle öldürüldü (Vassâf, 1346: 132). Şîrâzname'de diğer emirlerin öldürülmelerinden sonra Mecdeddin Rumînin bir süre daha İlhanlılara hizmet ettiği bilgisi verilmektedir. Mecdeddin Rûmînnin (1288-1290) iki y1llık idareciliğinden sonra yerine Şemsüd-devle tayin edildi (1290-1292). Salgurlu Atabegliği sonrası Fars bölgesindeki İlhanlı varlı̆̆ı, Geyhatu zamanında da devam etti. Şîrâz idaresi, Şemsüd-devle'den sonra Şeyh Cemaleddin'e verildi. Cemaleddin ve onun soyundan gelenler 1293-1325 y1llar1 arasinda İlhanlı temsilcisi olarak bölgeye hâkim oldu (Şîrâzî, 1310-1350: 71-73; Spuler, 2011: 377-378: Rençber, 2019: 88-89). ${ }^{15}$

${ }^{15}$ Salgurlu Atabegliği sonrası Şîrâz'daki İlhanlı hâkimiyeti konusunda bilgi için bk. (Uygur, 2019: 190 vd; Rençber, 2019: $83 \mathrm{vd})$. 


\section{Sonuç}

Atabeg unvanını taşıyan liderleri öncülüğ̈nnde hareket eden Salgurlular, kısa sürede geniş bir sahaya hükmeder duruma geldi. Salgurlu Atabegleri, en parlak zamanını yaşadığ dönemde Moğol tehlikesiyle karşı karşıya kaldı. İleri görüşlü liderler, itaatkâr bir tutum sergileyerek bir yandan Fars bölgesini Moğol saldırılarından korumak, diğer yandan devletin varlığını muhafaza edebilmek için Moğollara tabiliklerini bildirdi. Salgurlular'da devletin bekası için hareket eden atabegler arasında Naibe Türkan Hatun ve kızı Abiş Hatun da yer almaktadır.

Türk tarihinde devletlerin siyasî sürecinin işleyişinde ve sosyal hayatının düzenlenmesinde kadınların etkisi önemli ölçüde hissedildi. Kadınlar, vakıflar tesis edip hayır işleri ile meşgul oldukları gibi devletlerin idaresinde de nüfuz sahibi oldular. Devlet yönetimine ya eşleri ve oğulları vasıtasıyla ya da doğrudan katıldılar. Türk tarihinde pek çok örneği olan bu duruma, iki hatunun idarede bulunduğu Salgurlular da örnek gösterilebilir. Naibe Türkan Hatun ile başlayıp Abiş Hatun'la devam eden bu süreçte kadın liderler, devleti eski gücüne kavuşturmak için birçok girişimde bulundu. Salgurlular için tehlike oluşturan İlhanlılarla akrabalık bağı kurularak dostane bir siyaset sürdürülmeye çalışıldı. Tarihte bazı evliliklerin siyasî şartlar altında yapıldığı dikkate alınırsa Salgurlu Atabeglerinin bu evlilik sayesinde kendilerini İlhanlılara karşı korumak istedikleri ve Salgurlu Atabegliğinin bölgedeki varlı̆̆ını devam ettirmeyi amaçladıkları anlaşılmaktadır. Naibe Türkan'ın Selçuk-şâh ile evliliğindeki amacının da iktidarı elde tutmak, otoritenin devamını sağlamak olduğu açık bir şekilde görülmektedir. Türkan Hatun, oğlu Muhammed'i ve eşi Selçuk-şâh'ı naibeliğinin devamı için kullanırken, Abiş Hatun atabegliğini sürdürmede Han gelini olmasından ve İlhanlılarla akrabalığından istifade etti. Devlet idaresinde nüfuz sahibi olan hatunlar, liderlikleri süresince devlet yönetiminde ve Salgurlu emirleri üzerinde etkili oldu. Nüfuz ve otoritelerini sürdürebilmek için devlet adamlarından kendilerine yakın olanları önemli görevlere tayin ettiler ve gerekli durumda da bazılarını azlettiler.

Türkan ve Abiş Hatun, İlhanlılara karşı gösterdikleri tutumun yanı sıra isyanlar ve muhalif sesler karşısındaki dik duruşları sayesinde Salgurlular'ın yıkı1ışını bir süre daha ertelemeyi başardılar. Hırslı bir kadın olan Naibe Türkan Hatun, sahip olduğu nüfuz ve otoriteyle son gününe kadar tek başına karar verebilme kudretini muhafaza ederken, Abiş Hatun aynı kudreti gösteremedi. Abiş Hatun'un atabegliğiyle birlikte artan İlhanlı hâkimiyeti, karar alma mekanizmasını etkiledi. Bu sebeple Abiş Hatun, İlhanlı gölgesinde çıktığı tahtında İlhanlı emirleri kontrolünde varlığını devam ettirdi. Bağımsızlık elde etmek amacıyla girişimlerde bulunsa da tek başına karar verme yetkisini kullanamadı. Atabeg Abiş dönemi, emirler arasında nüfuz mücadelelerinin yaşandığı, malî soygunların arttığı bir süreç oldu.

Salgurlu yönetimindeki söz konusu iki kadının liderliği sıradan bir durum değildir. Hanedanın devamı için gerekli görülen bu liderliklerde cinsiyet karakterinin etkisi hissedilmemektedir. Tam aksine erkek liderlerin devleti koruma adına yaptığı işlerin aynı şekilde sürdürüldüğ̈u hatta bazı dönemlere göre bu girişimlerin daha baskın olduğu görülmektedir. Siyasî otoritenin sağlanması ve hanedanın devamı için yapılanlar, bu düşünceyi teyit etmektedir. Türkan Hatun ve Abiş Hatun'un devlet yönetimi şekline bakıldığında güçlü liderlik görüntüsü hissedilebilmektedir. Bu iki kadının da dâhil olduğu Salgurlu yöneticileri, siyasî başarılarıyla bölgeyi İlhanlı saldırılarından korumaya çalışırken hâkimiyet sahasındaki Türk varlığının da devamını sağlamışlardır. 


\section{Kaynakça}

Muhammed bin Ali bin Muhammed Şebânkâreî (1363). Mecmau'l-Ensâb, tsh. Mîr Hâşim Muhaddis, Tahran: İntişârât-1 Emîr Kebir.

ARICI, Mustakim (2017). "Bir Biyografinin Yeniden İnşası: Kâdî Beyzâvî, İlişki Ağları ve Eserleri”, İslâm İlim ve Düsünce Geleneğinde Kâdî Beyzâur̂, ed. Mustakim Arıc1, ss. 23-103, Ankara: İsam Yayınları.

AYAN, Ergin (2017). Ortaçağ Türk Devletlerinde Hanedan Evlilikleri, Ankara: Gece Kitaplığı.

BEYÂNÎ, Şîrîn (2015). Moğol Dönemi Iran'ında Kadın, çev. Mustafa Uyar, Ankara: Türk Tarih Kurumu Basimevi.

ÇALIŞKAN, Mehmet (2017). “Târih-i Güzîde’ye Göre Kirman Karahitayları”, İran Araștırmalar Dergisi, I(2): 35-43.

DAYI, Özkan (2020). Moğollarn Teşkilat ve İdarî Taribi İan Moğollar 1220-1295, Ankara: Altınordu Yayınları.

Ebû Abdullah Muhammed İbn Battûta Tancî (2004). İbn Battûta Seyahatâmesi I, çev. A. Sait Aykut, İstanbul: Yap1 Kredi Yayınları.

Ebû'l Abbâs Ahmed b. Ebû'l-Hayr Zerkûb Şîrâzî (1310-1350). Şîrâznâme, tsh. Behmen Kerîmî, Tahran: Matbâa Rûşenâî.

Fahreddîn Davud Benâketî (1348). Târih-i Benâketi, tsh. Ca'fer Şe’ar, Tahran.

GENÇTÜRK, Cihan (2016). "Kutlughanlilar'da Kadın Bir Nâibe: Kutlug Terken Hatun”, Bitlis Eren Üniversitesi Sosyal Bilimler Enstitüsü Dergisi, 5 (Ek Sayı): 97-112.

Hamdullah Müstevfî Kazvînî (1913). Tarih-i Gü̊ide, çev. Edward G. Browne-R. A. Nicholson, London.

Hamdullah Müstevfî Kazvînî (1919). Nǚhetü'l-Kulub, trans. G. L. Strange, London.

Kadî Ahmed Gaffârî̀ Kazvînî (1343). Tarih-i Cihan Ara, nşr. Hasan Nerakî, Tahran.

Abbas Kadyânî (1381). Ferbeng-i Câmi-i Tarib-i İran, Tahran.

KARAKOÇ, Haşim (1998). Kâdı Bezâvî ve Nizâmu't-Tevârîh’inin Edisyon Kritiği ve Tahlili, (Yayımlanmamış Yüksek Lisans Tezi), Kırıkkale Üniversitesi Sosyal Bilimler Enstitüsü, Kirikkale.

KASKA, Çetin (2019). “Sa'dî-i Şîrâzî ve Salgurlular”, Türk Taribi Araștırmaları Dergisi, Prof. Dr. Bahaeddin Ögel Sayısi, 4(1): 323-344.

KONTAMIR, Samira (2011). "Memlûk Toplumunda Kadın”, Ortaçağda Kadın, ed. Altan Çetin, ss. 605-620, Ankara: Lotus Yayınevi. $11-36$

MACİT, Ensar (2019). "Celâyirliler'de Kadın ve Siyaset”, Selçuklu Araștırmalar Dergisi, 11: Basimevi.

MERÇİL, Erdoğan (1991). Fars Atabegleri Salgurlular, Ankara: Türk Tarih Kurumu

Muhammed Mîrhând b. Burhâniddîn Hâvendşâh b. Kemâliddîn Mahmûd Herevî (1848). The History of the Atabegs of Syra and Persia, trc. William H. Morley, London.

OCAK, Ahmet (2011). "Selçuklu İlim ve Tefekkür Hayatında Kadınların Yeri”, Ortaçağ’da Kadın, ed. Altan Çetin, ss. 420-458, Ankara: Lotus Yayınevi. 
OKUMUŞ, Aydan (2012). Yezd Atabegliği, (1141-1318), (Yayımlanmamış Yüksek Lisans Tezi), Marmara Üniversitesi Türkiyat Araştırmaları Enstitüsü, İstanbul.

PIYADEOĞLU, Cihan (2011). "Büyük Selçuklu Coğrafyasında Yaşamış Kadın Âlimler", Ortaçă̆ da Kadın, ed. Altan Çetin, ss. 459-469, Ankara: Lotus Yayınevi.

RENÇBER, Akif (2019). "İlhanlılar İdaresinde Şîrâz (684/1286-735/1335)", İran Calismalarn Dergisi, 2(2): 83-101.

Reşîdüddîn Fazlullâh Hemedanî (1373). Camîï't-Tevarih II, tsh. Muhammed Rûşen, Mustafa Musevî, Tahran: Neşr-i Elburz.

Reşîdüddîn Fazlullâh Hemedanî (1947). Mukâtebât-ı Reşî̀î, nşr. Muhammed Şefî, Lahore.

Reşîüddîn Fazlullâh (2013). Câmin't-Tevârih (İhanhlar Kısmı), çev. İsmail Aka, Mehmet Ersan, Ahmad Hesamipour Khelejani, Ankara: Türk Tarih Kurumu.

SPULER, Bertold (2011). Iran Moğollar Siyaset, İdare ve Kültür İlhanllar Devri 1220-1350, Ankara: Türk Tarih Kurumu Basımevi.

SÜMER, Faruk (1988). “Abiş Hatun”, TDV İslam Ansiklopedisi, Cilt 1, ss. 310-311, İstanbul: Türk Diyanet Vakfi Yayınları.

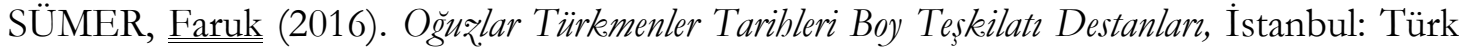
Dünyası Araştırmaları Vakfı.

Şerefeddin Abdullah b. İzzeddin Fadlullah b. Ebi Nuaym b. Yezdî Şirâzî (1346). Tabrir-i Tarih-i V assâf, nşr. Abdülmuhammed Âyeti, Tahran: İntişarat-1 Bünyad-1 Ferheng-i İran.

Şeyh Sâdî-1̂ Şîrâzî(1980). Bostan ve Gülistan, trc. Kilisli Rıfat Bilge, İstanbul: Meral Yayınevi.

BENJAMIN, Tudela'lı ve Ratisbon'lu Petachı (2009). Ortaşağda İki Yabudi Seyyahın İslâm Dünyası Gö̊lemleri, çev. Nuh Arslantaş, İstanbul: M.Ü. İlahiyat Fakültesi Vakfi Yayınları.

UYGUR, Türker (2019). İlhanlılar Zamanında Șirâz Şehri (1256-1335), (Yayımlanmamış Doktora Tezi), Harran Üniversitesi Sosyal Bilimler Enstitüsü, Şanlıurfa. Kültür Sanat.

ÜÇOK, Bahriye (2011). İslâm Devletlerinde Türk Nâibeler ve Kadın Hükümdarlar, İstanbul: Bilge

YUVALI, Abdulkadir (2017). İlhanh Taribi, İstanbul: Bilge Kültür Sanat.

ÖZTUNA, Yılmaz (1989). İslâm Devletleri Devletler ve Hanedanlar, Cilt 1, Ankara: Kültür Bakanlı̆̆ Yayınları. 